\title{
Synthesis and Antitubercular Activity of Heteroaromatic Isonicotinoyl and 7-Chloro- 4-Quinolinyl Hydrazone Derivatives
}

\author{
Marcelle de L. Ferreira ${ }^{1,2}$, Raoni S.B. Gonçalves ${ }^{1,2}$, Laura N. de F. Cardoso ${ }^{1}$, \\ Carlos R. Kaiser ${ }^{2}$, André L.P. Candéa ${ }^{1}$, Maria das Graças M. de O. Henriques ${ }^{1}$, \\ Maria C.S. Lourenço ${ }^{3}$, Flávio A.F.M. Bezerra ${ }^{3}$, and Marcus V.N. de Souza ${ }^{1, *}$ \\ ${ }^{1}$ FioCruz-Fundação Oswaldo Cruz, Instituto de Tecnologia em Fármacos-Far Manguinhos, \\ Manguinhos, Rio de Janeiro; ${ }^{2}$ Departamento de Química Orgânica, Instituto de Química, \\ Universidade Federal do Rio de Janeiro, Rio de Janeiro; ${ }^{3}$ Instituto de Pesquisas Clínica \\ Evandro Chagas - IPEC, Manguinhos, Rio de Janeiro \\ E-mail: marcos souza@far.fiocruz.br
}

Received February 24, 2010; Revised May 13, 2010; Accepted May 26, 2010; Published July 7, 2010

Two series of $N^{\prime}-(E)$-heteroaromatic-isonicotinohydrazide derivatives (3a-f and $\left.4 a-b\right)$ and 1-(7-chloroquinolin-4-yl)-2-[(heteroaromatic)methylene]hydrazone derivatives (5a-f and 6a-b) have been synthesized and evaluated for their in vitro antibacterial activity against Mycobacterium tuberculosis $\mathrm{H}_{37} R \mathbf{R}$. Several compounds were noncytotoxic and exhibited significant minimum inhibitory concentration (MIC) activity $(3.12,2.50,1.25$, or 0.60 $\mu \mathrm{g} / \mathrm{mL})$, which can be compared to that of the first-line drugs ethambutol $(3.12 \mu \mathrm{g} / \mathrm{mL})$ and rifampicin $(2.0 \mu \mathrm{g} / \mathrm{ml})$. These results can be considered an important starting point for the rational design of new leads for anti-TB compounds.

KEYWORDS: tuberculosis, quinoline, isoniazid, drugs

\section{INTRODUCTION}

Tuberculosis (TB) is the most important infectious cause of death worldwide. According to the World Health Organization (WHO), more than 2 billion people are infected with TB bacilli (Mycobacterium tuberculosis) and a total of 1.77 million people died from TB in 2007[1]. The lack of new anti-TB drugs, the coinfection with HIV/AIDS, and the advent of resistant strains to the current therapy are the main causes responsible for TB resurgence[2]. Among these problems, the emergence of drug-resistant TB is especially alarming. According to the WHO, 511,000 cases of multidrug-resistant TB (MDR-TB), strains resistant to isoniazid and rifampicin, occurred in 2007 (4.9\% of all cases). Among these cases, 289,000 were new cases and 221,000 were cases that had been previously treated for TB. Another important factor in TB treatment worldwide is the advent of extensively drug-resistant TB (XDR-TB), which is commonly defined as MDRTB plus resistance to any fluorquinolone and to, at least, one of the three injectable second-line anti-TB drugs used in TB treatment (capreomycin, kanamycin, and amikacin)[1,3]. By the end of 2008, 55 countries and territories had reported at least one case of XDR-TB. The WHO estimates that $19 \%$ of MDR cases are in fact XDR-TB and the cure is possible for up to $50-60 \%$ of the people affected[1]. 
Due to the high impact of MDR and XDR in TB treatment, there is an urgent need for new drugs to treat this disease efficiently. In this context, isoniazid (INH) derivatives have been found to possess potential anti-TB activities[4,5,6]. INH is one of the most powerful synthetic agents against the $M$. tuberculosis complex and it has an important bactericidal activity against the replicating bacteria. Moreover, INH is a prodrug, which needs a previous in vivo activation to exercise its anti-TB activity. The enzyme responsible for this function is called KatG. After INH activation, an isonicotinoyl radical is produced, which reacts with the nicotinamide group of NAD (nicotinamide adenine dinucleotide) to yield the INH-NAD adduct. This adduct mainly inhibits and binds to trans-2-enoyl-ACP reductase, encoded by the InhA gene, which promotes the elongation phase of the FAS-II (fatty acid synthetase II) system. The inhibition of this enzyme interrupts the mycolic biosynthesis leading to cell lysis[7].

Due to the significance of this drug for TB treatment, the advent of INH-resistant strains is very alarming. The majority of INH-resistant strains demonstrate deletion or point mutations in the $M$. tuberculosis katG gene, which is responsible for INH activation[8]. Moreover, it is probable that $\mathrm{Mn}^{3+}$ ions could facilitate the formation of isonicotinic acyl radicals and KatG participates in isoniazid activation by increasing the rate of the conversion of $\mathrm{Mn}^{2+}$ to $\mathrm{Mn}^{3+}$ ions. Due to the ability of hydrazone derivatives in metal chelation[9] and generation of metal ion-induced radical intermediates[10,11,12], we decided to investigate the potential anti-TB activity of a series of heteroaromatic hydrazones derived from INH (3a-f and 4a-b, see Scheme 1). Another aim of this article is to compare the biological activity of the INH derivatives to a series of heteroaromatic 7-chloro-4-quinolinylhydrazones (5a-f and 6a-b, see Scheme 1). Recently, we reported the synthesis and anti-TB activity of a series of monosubstituted 7chloro-4-quinolinylhydrazones, which demonstrated relevant minimum inhibitory concentration (MIC) between 12.5 and $2.5 \mu \mathrm{g} / \mathrm{mL}[13]$. Hence, this report is also very important in order to continue the study of the structure-activity relationship of this class of compounds.

The criteria used to select the five-member heterocyclic nuclei was based on isosteric replacements: (1) substitution of the oxygen atom of the furane ring (1a) by sulfur (1d) or nitrogen (1e) and (2) substitution of $-\mathrm{CH}=$ by $-\mathrm{N}=$ in the pyrrole ring (1e) to give an imidazole ring (1) ; whereas the sixmember heterocyclic (2a-b) was chosen in order to analyze the influence of the introduction of the nitrogen atom in the phenyl ring on the biological activity of this series.

\section{EXPERIMENTAL PROCEDURES}

\section{General Procedures}

Melting points were determined on a Buchi apparatus and are uncorrected. Infrared spectra were recorded in a Thermo Nicolet Nexus 670 spectrometer, as potassium bromide pellets and frequencies are expressed in $\mathrm{cm}^{-1}$. Mass spectra (ESI assay in solution of ammonium chloride) were recorded in Micromass ZQ Waters mass spectrometer. NMR spectra were recorded in a Bruker Avance 400 operating at $400.00 \mathrm{MHz}$ $\left({ }^{1} \mathrm{H}\right)$ and $100.0 \mathrm{MHz}\left({ }^{13} \mathrm{C}\right)$, and Bruker Avance 500 spectrometer operating at $500.00 \mathrm{MHz}\left({ }^{1} \mathrm{H}\right)$ and 125.0 $\mathrm{MHz}\left({ }^{13} \mathrm{C}\right)$, in deuterated dimethylsulfoxide. Chemical shifts are reported in $\mathrm{ppm}(\delta)$ relative to tetramethylsilane and $J$-coupling in Hertz $(\mathrm{Hz})$. Proton and carbon spectra were typically obtained at room temperature. TLC plates, coated with silica gel, were run in a chloroform/methanol (9:1) mixture and spots were developed in ultraviolet and solution of ninhidrine $(0.2 \% \mathrm{p} / \mathrm{v}$ in ethanol).

\section{General Procedures for Synthesis of $N^{\prime}-(E)$-Heteroaromatic-Isonicotinohydrazide Derivatives (3a-f and 4a-b)}

The synthesis of $N^{\prime}-(E)$-heteroaromatic-isonicotinohydrazide derivatives (3a-f and 4a-b) was prepared by the reaction between isoniazid (1.0 equiv.) and the appropriate heteroaromatic aldehyde (1a-f and 2a-b) (1.2 equiv.) in a mixture of ethanol and water distillate $(1: 1,10 \mathrm{~mL})$; initially, dissolving isoniazid in 
water distillate $(5 \mathrm{~mL})$ and adding the respective heteroaromatic aldehyde in ethanol $(5 \mathrm{~mL})$. After stirring for 4-24 $\mathrm{h}$ at room temperature, the resulting mixture was concentrated under reduced pressure and the residue purified by washing with cold $\mathrm{Et}_{2} \mathrm{O}(3 \times 10 \mathrm{~mL})$, leading to the pure derivatives (3a-f and $\left.\mathbf{4 a - b}\right)$ as a solid in $56-91 \%$ yields.

$\mathrm{N}^{\prime}-[(\mathrm{E})-(1 \mathrm{H}-$ Imidazol-2-yl)Methylidene]Isonicotinohydrazide (3f)

Yield: 56\%; mp: $198-200{ }^{\circ} \mathrm{C}$; ${ }^{1} \mathbf{H}$ NMR[500 MHz (FIDRES \pm 0.15 Hz), DMSO- $\boldsymbol{d}_{\boldsymbol{6}}$ ] $\delta$ : 13.38 (1H; br; $\mathrm{N} \underline{\mathrm{H}}) ; 12.08(1 \mathrm{H} ; \mathrm{br} ; \mathrm{N} \underline{\mathrm{H}}) ; 8.80\left(2 \mathrm{H} ; \mathrm{d} ; J=5.5 \mathrm{~Hz} ; \mathrm{H}_{2}\right.$ and $\left.\mathrm{H}_{6}\right) ; 8.37(1 \mathrm{H} ; \mathrm{s} ; \mathrm{N}=\mathrm{C}-\underline{\mathrm{H}}) ; 7.84\left(2 \mathrm{H} ; \mathrm{br} ; \mathrm{H}_{3}\right.$ and

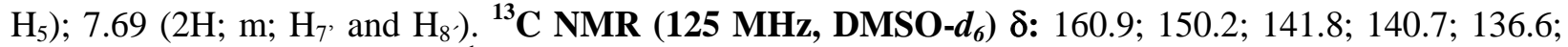
122.3; 121.4 ppm. IVv $v_{\max }\left(\mathbf{c m}^{-\mathbf{1}}\right.$; KBr pellets): $3233(\mathrm{~N}-\mathrm{H}) ; 1655(\mathrm{C}=\mathrm{O})$. MS/ESI: $m / z[\mathrm{M}-\mathrm{H}]^{+}: 214$.

\section{General Procedures for Synthesis of 7-Chloro-4-Quinolinylhydrazone Derivatives (5a-f and 6a-b)[13]}

The 7-chloro-4-quinolinylhydrazone derivatives (5a-f and $\mathbf{6 a - b})$ were obtained by the reaction between 7chloro-4-hydrazinoquinoline (1.03 mmols) and the appropriate heteroaromatic aldehyde (1a-f and 2a-b) $(1.24 \mathrm{mmols})$ in ethanol $(5 \mathrm{~mL})$. After stirring for 3-30 $\mathrm{h}$ at room temperature, the resulting mixture was concentrated under reduced pressure and the residue purified by washing with cold $\mathrm{Et}_{2} \mathrm{O}(3 \times 10 \mathrm{~mL})$, leading to the pure derivatives (5a-f and $\mathbf{6 a - b}$ ) as solids in $58-92 \%$ yields.

\section{1-(7-Chloroquinolin-4-yl)-2-[(5-Nitro-Furan-2-yl)Methylene]Hydrazine (5a)}

Yield: $85 \%$; mp: $238-240^{\circ} \mathrm{C} ;{ }^{1} \mathbf{H}$ NMR[500 MHz (FIDRES $\pm \mathbf{0 . 1 5}$ Hz), DMSO-d $\left.\boldsymbol{d}_{6}\right]$ $\delta$ : 11.70 (1H; br; $\mathrm{NH}), 8.35\left(2 \mathrm{H} ; \mathrm{m} ; \mathrm{H}_{2}\right.$ and $\left.\mathrm{H}_{5}\right), 8.30(1 \mathrm{H} ; \mathrm{s} ; \mathrm{N}=\mathrm{C}-\underline{\mathrm{H}}), 7.81\left(2 \mathrm{H} ; \mathrm{d} ; J=3.7 \mathrm{~Hz} ; \mathrm{H}_{7}\right.$ and $\left.\mathrm{H}_{6}\right), 7.55(1 \mathrm{H} ; \mathrm{br}$; $\left.\mathrm{H}_{8}\right)$; 7.22-7.26 $\left(2 \mathrm{H} ; \mathrm{m} ; \mathrm{H}_{3}\right.$ and $\left.\mathrm{H}_{8}\right)$. IVv $\mathbf{v}_{\max }\left(\mathbf{c m}^{-1}\right.$; KBr pellets): $3158(\mathrm{~N}-\mathrm{H}) ; 1571(\mathrm{C}=\mathrm{N})$. MS/ESI: $m / z[\mathrm{M}-\mathrm{H}]^{+}: 315$.

\section{1-(7-Chloroquinolin-4-yl)-2-[(5-Nitro-Thiophen-2-yl)Methylene]Hydrazine (5c)}

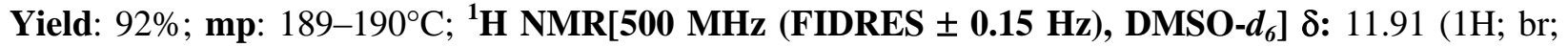
$\mathrm{N} \underline{\mathrm{H}}), 8.55\left(2 \mathrm{H} ; \mathrm{m} ; \mathrm{H}_{2}\right.$ and $\left.\mathrm{H}_{5}\right), 8.22(1 \mathrm{H} ; \mathrm{s} ; \mathrm{N}=\mathrm{C}-\underline{\mathrm{H}}), 8.08\left(1 \mathrm{H} ; \mathrm{d} ; J=4.4 \mathrm{~Hz} ; \mathrm{H}_{7}\right) ; 7.53(1 \mathrm{H} ; \mathrm{d} ; J=1.9$ $\left.\mathrm{Hz} ; \mathrm{H}_{8}\right) ; 7.48-7.51\left(2 \mathrm{H} ; \mathrm{m} ; \mathrm{H}_{8^{\prime}}\right.$ and $\left.\mathrm{H}_{6}\right) ; 6.98\left(1 \mathrm{H} ; \mathrm{d} ; J=7.4 \mathrm{~Hz} ; \mathrm{H}_{3}\right) . \mathbf{I V v}_{\max }\left(\mathbf{c m}^{-1}\right.$; KBr pellets): 3182 $(\mathrm{NH}) ; 1585(\mathrm{C}=\mathrm{N})$. MS/ESI: $m / z[\mathrm{M}+\mathrm{H}]^{+}: 333$.

\section{1-(7-Chloroquinolin-4-yl)-2-[(2-Pyridyl)Methylene]Hydrazine (6a)}

Yield: $61 \%$; mp: $210-211^{\circ} \mathrm{C} ;{ }^{1} \mathbf{H}$ NMR[500 MHz (FIDRES $\pm \mathbf{0 . 1 5} \mathbf{~ H z}$ ), DMSO- $\boldsymbol{d}_{\boldsymbol{\sigma}}$ ] $\delta$ : 11.46 (br; $1 \mathrm{H}$; $\mathrm{N} \underline{\mathrm{H}}), 8.61\left(2 \mathrm{H} ; \mathrm{m} ; \mathrm{H}_{2}\right.$ and $\left.\mathrm{H}_{5}\right) ; 8.41(1 \mathrm{H} ; \mathrm{s} ; \mathrm{N}=\mathrm{C}-\underline{\mathrm{H}}), 8.38\left(1 \mathrm{H} ; \mathrm{d} ; J=7.9 \mathrm{~Hz} ; \mathrm{H}_{6}\right.$-or $\left.\mathrm{H}_{9}{ }^{\prime}\right), 8.09(1 \mathrm{H} ; \mathrm{d} ; J=$ $7.9 \mathrm{~Hz} ; \mathrm{H}_{6}$ or $\mathrm{H}_{9}$ ), 7.85-7.88 $\left(2 \mathrm{H} ; \mathrm{m} ; \mathrm{H}_{8}\right.$ and $\mathrm{H}_{7^{\prime}}$ or $\left.\mathrm{H}_{8^{\prime}}\right), 7.56\left(1 \mathrm{H} ; \mathrm{br} ; \mathrm{H}_{6}\right), 7.37-7.45\left(2 \mathrm{H} ; \mathrm{m} ; \mathrm{H}_{3}\right.$ and $\mathrm{H}_{7}$, or $\left.\left.\mathrm{H}_{8}\right)\right) . \mathbf{I V v}_{\max }\left(\mathbf{c m}^{-1}\right.$; KBr pellets): $3419(\mathrm{~N}-\mathrm{H}) ; 1442(\mathrm{C}=\mathrm{N})$. MS/ESI: $m / z[\mathrm{M}-\mathrm{H}]^{+}: 281$. 


\section{General Procedures for Biological Tests}

\section{Antimycobacterial Activity}

Briefly, $200 \mu \mathrm{L}$ of sterile deionized water was added to all outer-perimeter wells of sterile 96 well plates (falcon, 3072: Becton Dickinson, Lincoln Park, NJ) to minimize evaporation of the medium in the test wells during incubation. The 96 plates received $100 \mu \mathrm{L}$ of the Middlebrook 7H9 broth (Difco Laboratories, Detroit, MI) and a serial dilution of the compounds (3a-f, 4a-b, 5a-f, and 6a-b) was made directly on the plate. The final drug concentration tests were $0.01-100 \mu \mathrm{g} / \mathrm{mL}$. Plates were covered and sealed with parafilm and incubated at $37^{\circ} \mathrm{C}$ for 5 days. After this time, $25 \mu \mathrm{L}$ of a freshly prepared 1:1 mixture of Alamar Blue (Accumed International, Westlake, $\mathrm{OH}$ ) reagent and 10\% Tween 80 was added to the plate and incubated for $24 \mathrm{~h}$. A blue color in the well was interpreted as no bacterial growth and a pink color was scored as growth. The MIC was defined as the lowest drug concentration, which prevented a color change from blue to pink.

\section{Cell Viability Assay}

The cellular viability for a macrophage cell line J774 (ATCC TIB-67 ${ }^{\mathrm{TM}}$ ) was determined by Mosman's MTT (3-(4,5-dimethylthylthiazol-2yl)-2,5-dimethyl tetrazolium bromide; Merck) microcultured tetrazolium assay. We evaluated macrophages in the presence and absence of test compounds (3a-c, 3e-f, 4a-b, 5a-f, and 6a). The cells were plated in flat-bottom 96 well plates $\left(2.5 \times 10^{6}\right.$ cells/well/100 $\left.\mu \mathrm{L}\right)$ cultured for $24 \mathrm{~h}$ in a controlled atmosphere $\left(\mathrm{CO}_{2} 5 \%\right.$ at $\left.37^{\circ} \mathrm{C}\right)$, and nonadherent cells were washed by gentle flushing with RPMI 1640 supplemented with fetal bovine serum (10\%) and gentamicin $(25$ $\mu \mathrm{g} / \mathrm{mL})$. Adherent cells were infected or not with BCG $\left(2.5 \times 10^{6} \mathrm{UFC} /\right.$ well/100 $\left.\mu \mathrm{L}\right)$ cultured in the presence of medium alone, Tween 20 (3\%) (live and dead controls, respectively), or different concentrations of compounds $(1.0,10.0$, and $100 \mu \mathrm{g} / \mathrm{mL})$ in a triplicate assay. After $48 \mathrm{~h}$, stock MTT solution $(5 \mathrm{mg} / \mathrm{mL}$ of saline; $20 \mathrm{~mL} /$ well $)$ was added to the culture and $4 \mathrm{~h}$ later, the plate was centrifuged for $2 \mathrm{~min}$ at $2800 \mathrm{rpm}$, supernatant was discharged, and dimethyl sulfoxide (DMSO) (100 $\mu \mathrm{L} / \mathrm{well}$ ) was added to formazan crystals solubilization, and the absorbance was ready at $540 \mathrm{~nm}$ in a plate reader (Biorad - 450).

\section{RESULTS AND DISCUSSION}

\section{Chemistry}

The synthetic routes for the preparation of the $N^{\prime}-(E)$-heteroaromatic-isonicotinohydrazide derivatives (3a-f and 4a) and the heteroaromatic 7-chloro-4-quinolinylhydrazone derivatives (5a-f and 6a-b) are summarized in Scheme 1. Basically, these compounds were obtained from reactions of isoniazid or 7chloro-4-hydrazinoquinoline and heteroaromatic aldehydes in $\mathrm{EtOH}: \mathrm{H}_{2} \mathrm{O}$ (1:1) or $\mathrm{EtOH}$ at room temperature, respectively (Scheme 1 and Table 1).

All the compounds were identified by the spectral data. In general, IR spectra of INH derivatives (3af and 4a-b) showed the $\mathrm{C}=\mathrm{O}$ peak at $1648-1678 \mathrm{~cm}^{-1}$ and the $\mathrm{NH}$ stretching vibrations at 3015-3270 $\mathrm{cm}^{-1}$. The nuclear magnetic resonance spectra $\left({ }^{1} \mathrm{H} \mathrm{NMR}\right)$ showed the hydrazide $(\mathrm{NH})$ proton as a singlet at $12.46-11.78 \mathrm{ppm}$ and the imine proton $(\mathrm{N}=\mathrm{C}-\mathrm{H})$ at $8.78-8.37 \mathrm{ppm}$. The ${ }^{13} \mathrm{C}$ NMR spectrum showed the $\mathrm{C}=\mathrm{O}$ signals at $161.9-161.4 \mathrm{ppm}$ and $\mathrm{C}=\mathrm{N}$ signals at $146.1-140.1 \mathrm{ppm}$. For the quinoline derivatives (5a-f and 6a-b), the IR spectra showed the $\mathrm{N}=\mathrm{C}$ stretching vibration at $1612-1576 \mathrm{~cm}^{-1}$. Specifically, in the ${ }^{1} \mathrm{H}$ NMR spectra, the imine proton $(\mathrm{N}=\mathrm{C}-\underline{\mathrm{H}})$ appears as a singlet in the range 8.81-8.29 ppm. 


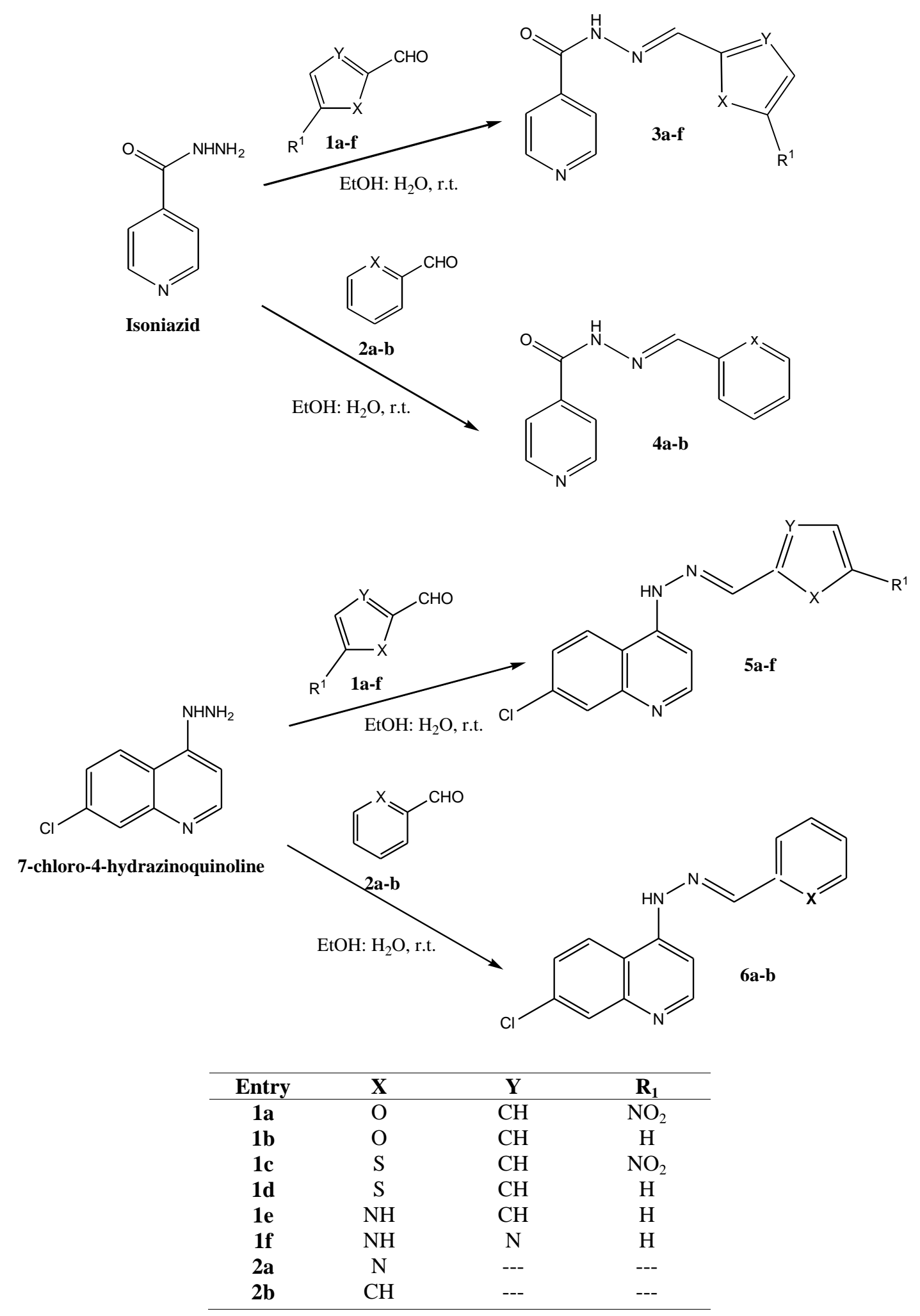

SCHEME 1. Synthetic routes for the preparation of the $N^{\prime}-(E)$-heteroaromatic-isonicotinohydrazide derivatives (3a-f and 4ab) and the heteroaromatic 7-chloro-4-quinolinylhydrazone derivatives (5a-f and 6a-b). 
TABLE 1

Yields and Melting Points of Isonicotinoyl Hydrazones and 7-Chloro-4-Quinolinylhydrazones (3a-f, 4a-b, 5a-f, and 6a-b)

\begin{tabular}{lcc}
\hline Entry & Yield (\%) & m.p. $\left({ }^{\circ} \mathbf{C}\right)$ \\
\hline $3 a$ & 75 & $184-186[14]$ \\
$3 b$ & 82 & $179[15]$ \\
$3 c$ & 90 & $188-189[14]$ \\
$3 d$ & 87 & $224-226[15]$ \\
$3 e$ & 91 & $234-235[16]$ \\
$3 f$ & 56 & $198-200$ \\
$4 a$ & 79 & $122[15]$ \\
$4 b$ & 83 & $160-161[17]$ \\
$5 a$ & 85 & $238-240$ \\
$5 b$ & 78 & $210-212[18]$ \\
$5 c$ & 92 & $189-190$ \\
$5 d$ & 83 & $231-232[18]$ \\
$5 e$ & 82 & $219-220[18]$ \\
$5 f$ & 58 & $274-275[18]$ \\
$6 a$ & 61 & $210-211$ \\
$6 b$ & 70 & $223-225[13]$ \\
\hline
\end{tabular}

\section{Antimycobacterial Activity}

The antimycobacterial activities of the derivatives 3a-f, 4a-b, 5a-f, and 6a-b were assessed against $M$. tuberculosis ATCC 27294[19] using the microplate Alamar Blue assay (MABA)[20] (Table 2). This nontoxic methodology uses a thermally stable reagent, and shows good correlation with proportional and BACTEC radiometric methods[21,22].

When these two different series of compounds were compared, it was observed that among the compounds with five-member heterocyclic nucleus (3a-f vs. 5a-f), the quinoline derivatives are more active than INH derivatives, except in the case of $\mathbf{3 e}$ and 5e. However, the comparison between the sixmember compounds (4a-b vs. 6a-b) showed that INH derivatives were more active than quinoline derivatives. These data might indicate that biological activity of quinoline derivatives is more susceptible to bulk effects than INH derivatives. This hypothesis can be more detailed if we compare the fivemember heterocyclic nucleus [5d $(\mathrm{S}), \mathbf{5 b}(\mathrm{O}), \mathbf{5 e}(\mathrm{NH})$, and $\mathbf{5 f}(\mathrm{N}$ plus $\mathrm{NH})$ ] bounded to quinoline derivatives. It was observed that there is no difference in the biological activity of these compounds (all derivatives showed MIC $=3.12 \mu \mathrm{g} / \mathrm{mL}$ ), but with the increase of size ring (six-member compounds, $6 \mathbf{a}$ and $\mathbf{6 b}$ ), the biological activity decreases four times in the case of $\mathbf{6 a}$ or completely disappears in the case of $6 \mathbf{b}$.

Furthermore, when the compounds are compared into the same series ( $\mathbf{3 a}$ vs. $\mathbf{3 b}$, $\mathbf{5 a}$ vs. $\mathbf{5 b}$, and $\mathbf{5 c}$ vs. 5d), it was observed that all the nitro derivatives (3a, 5a, and 5c) were more active than the other compounds (3b, $\mathbf{5 b}$, and $\mathbf{5 d}$ ), suggesting that the nitro group is an important feature to modulation of biological activity in these series.

Moreover, when the derivatives $4 \mathbf{a}$ and $\mathbf{4 b}, \mathbf{6} \mathbf{a}$ and $\mathbf{6 b}$ are compared, it was observed that the compounds without the nitrogen atom were less active, suggesting that the presence of this atom in the six-member compounds also seems to be important for the biological activity in both series. 
TABLE 2

Antimycobacterial Activities and clogP Measurements of INH and 7-Chloro-4-Quinolinylhydrazone Derivatives (3a-f, 4a-b, 5a-f, and 6a-b)

\begin{tabular}{lccccc}
\hline Entry & $\begin{array}{c}\mathbf{M I C}^{\mathbf{a}} \\
(\boldsymbol{\mu} \mathbf{g} / \mathbf{m L})\end{array}$ & $\boldsymbol{c L o g} \boldsymbol{P}^{\mathbf{b}}$ & Entry & $\begin{array}{c}\mathbf{M I C}^{\mathbf{a}} \\
(\boldsymbol{\mu} \mathbf{g} / \mathbf{m L})\end{array}$ & $\boldsymbol{c L o g} \boldsymbol{P}^{\mathbf{b}}$ \\
\hline 3a & 3.12 & 1.07 & $5 \mathrm{a}$ & 2.50 & 4.99 \\
3b & 25 & 1.15 & $5 \mathrm{~b}$ & 3.12 & 4.91 \\
3c & 1.25 & 1.71 & $5 \mathrm{c}$ & 1.25 & 5.63 \\
3d & $\mathrm{N} . \mathrm{D} .^{\mathrm{c}}$ & 1.79 & $5 \mathrm{~d}$ & 3.12 & 5.52 \\
3e & 1.25 & 0.96 & $5 \mathrm{e}$ & 3.12 & 4.81 \\
3f & 25 & -0.10 & $5 \mathrm{f}$ & 3.12 & 3.75 \\
4a & 0.60 & 1.81 & $6 \mathrm{a}$ & 12.5 & 4.36 \\
4b & 3.12 & 0.64 & $6 \mathrm{~b}$ & Resistant & 5.65 \\
Isoniazid & 0.2 & -0.97 & Isoniazid & 0.2 & -0.97 \\
\hline
\end{tabular}

a Minimum inhibitory concentration.

b Calculated using www.molinspiration.com.

c N.D. = not determined due to the occurrence of color interference during the assay.

\section{Cell Viability Assay}

All the active compounds (3a-c, 3e-f, 4a-b, 5a-f, and 6a) were selected for evaluation of their cytotoxicities by Mosman's assay. The cellular viability in the presence and absence of the test compounds (3a-c, 3e-f, 4a-b, 5a-f, and 6a) was determined by Mosman's MTT (3-(4.5demethylthylthiazol-2-yl)-2.5-dimethyltetrazolium bromide; Merck) microcultured tetrazolium assay[23,24]. The results were represented as percentage cell viability (Table 3).

TABLE 3

Data of the Cellular Viability for a Macrophage Cell Line J774 (ATCC TIB-67 ${ }^{\mathrm{TM}}$ ) by Mosman's Assay

\begin{tabular}{|c|c|c|c|c|c|c|c|}
\hline \multirow{2}{*}{ Entry } & \multicolumn{3}{|c|}{$\%$ Cell Viability/Dose $(\mu \mathrm{g} / \mathrm{ml})$} & \multirow{2}{*}{ Entry } & \multicolumn{3}{|c|}{$\%$ Cell Viability/Dose $(\mu \mathrm{g} / \mathrm{ml})$} \\
\hline & 1 & 10 & 100 & & 1 & 10 & 100 \\
\hline 3a & 91 & 80 & 95 & $5 a$ & 90 & 100 & 17 \\
\hline $3 b$ & 91 & 90 & 87 & $5 b$ & 78 & 65 & 10 \\
\hline $3 c$ & 95 & 80 & 45 & $5 c$ & 97 & 87 & 36 \\
\hline $3 d$ & - & - & - & $5 d$ & 95 & 89 & 28 \\
\hline $3 e$ & 92 & 95 & 89 & $5 e$ & 86 & 25 & 13 \\
\hline $3 f$ & 80 & 76 & 58 & $5 f$ & 82 & 84 & 15 \\
\hline $4 a$ & 96 & 100 & 53 & $6 a$ & 100 & 27 & 13 \\
\hline $4 b$ & 95 & 98 & 74 & $6 b$ & - & - & - \\
\hline Isoniazid & 97 & 100 & 100 & Isoniazid & 97 & 100 & 100 \\
\hline
\end{tabular}


This table shows that the compounds 3a-c, 3e, 4a-b, 5a, 5c-d, and $6 \mathbf{a}$ did not kill more than $10 \%$ of the host cells in the minimum concentration tested. In general, INH derivatives were less cytotoxic than quinoline derivatives. Another important observation is that the presence of the nitro group in these compounds did not lead to the increase of their cytotoxicities (see $\mathbf{3 a}$ vs. $\mathbf{3 b}, \mathbf{5 a}$ vs. $\mathbf{5 b}$, and $\mathbf{5 c}$ vs. $\mathbf{5 d}$ ).

\section{CONCLUSION}

The synthesis of $16 \mathrm{INH}$ and 7-chloro-4-hydrazinoquinoline heteroaromatic hydrazone derivatives (3a-f, 4a-b, 5a-f, and 6a-b) was performed in good yields (56-92\%). Among them, four are new compounds (3f, 5a, 5c, and 6a). All these compounds were submitted to antimycobacterial activity evaluation and 14 derivatives (3a-c, 3e-f, 4a-b, 5a-f, and 6a) exhibited MIC values between 25 and $0.60 \mu \mathrm{g} / \mathrm{mL}$. Therefore, these compounds were selected for the evaluation of their cytotoxicities by Mosman's assay. Among these derivatives, 3a-c, 3e, 4a, 5a, 5c-d, and 6a were not cytotoxic to host cells in the effective concentrations to inhibit the growth of $M$. tuberculosis. Furthermore, the compounds 3a, 3c, 3e, 4a, 5a, $\mathbf{5 c}$, and $\mathbf{5 d}$ exhibited a significant activity $(3.12,2.50,1.25$, or $0.60 \mu \mathrm{g} / \mathrm{mL})$ when compared to the firstline drugs, such as ethambutol (MIC $=3.12 \mu \mathrm{g} / \mathrm{mL})$ and rifampicin $(2.0 \mu \mathrm{g} / \mathrm{ml})$, and could be considered a good starting point to find new lead compounds in the fight against TB.

\section{REFERENCES}

1. $\quad$ http://www.who.int/topics/tuberculosis/en/ (date of access: 01-30-2010)

2. De Souza, M.V.N. (2006) Promising drugs against tuberculosis. Rec. Pat. Anti-Infect. Drug Discov. 1, $33-45$.

3. De Souza, M.V.N. (2009) Promising candidates in clinical trials against multidrug-resistant tuberculosis (MDR-TB) based on natural products. Fitoterapia 80, 453-460.

4. Lourenco, M.C., Ferreira, M.L., De Souza, M.V.N., Peralta, M.A., Vasconcelos, T.A., and Henrique, M.G.M.O. (2008) Synthesis and anti-mycobacterial activity of of (E)-N-(monosubstituted-benzylidene)isonicotinohydrazide derivatives. Eur. J. Med. Chem. 43, 1344-1347.

5. De Souza, M.V.N., Neves Junior, I., Miranda, G.B.P., Lourenco, M.C.S., Vasconcelos, T.A., Pais, K.C., Wardell, J.L., Wardell, S.M.S.V., and Alcântara Junior, J.P. (2006) Synthesis and in vitro anti-tubercular activity of a series of N'(disubstitutedbenzoyl)isoniazid derivatives. Lett. Drug Des. Discov. 3, 424-428.

6. De Souza, M.V.N., Vasconcelos, T.R.A., Mello, S.C.P., Wardell, S.M.S.V., Peralta, M.A., Ferreira, B., Henrique, M.G.M.O., Neves Junior, I., and Lourenco, M.C.S. (2005) Synthesis and anti-mycobacterial activity of N’[(E)(disubstituted-phenyl)methylidene]isonicotino-hydrazine derivatives. Lett. Drug Des. Discov. 2, 563-566.

7. De Souza, M.V.N., Ferreira, M.L., Pinheiro, A.C., Saraiva, M.F., Almeida, M.V., and Valle, M.S. (2008) Synthesis and biological aspects of mycolic acids: an important target against Mycobacterium tuberculosis. TheScientificWorldJOURNAL 8, 720-751.

8. Heym, B., Saint-Joanis, B., and Cole, S.T. (1999) The molecular basis of isoniazid resistance in Mycobacterium tuberculosis. Tuber. Lung Dis. 79(4), 267-271.

9. Zelenin, K.N., Khorseeva, L.A., and Alekseev, V.V. (1992) Physiologically active complexes of hydrazones. Pharm. Chem. J. 26(5), 395-405.

10. Gemma, S., Savini, L., Altarelli, M., Tripaldi, P., Chiasserini, L., Coccone, S.S., Kumar, V., Camodeca, C., Campiani, G., Novellino, E., Clarizio, S., Delogu, G., and Butini, S. (2009) Development of antitubercular compounds based on a 4-quinolylhydrazone scaffold. Further structure-activity relationship studies. Bioorg. Med. Chem. 17, 6063-6072.

11. Richardson, D.R., Sharpe, P.C., Lovejoy, D.B., Senaratne, D., Kalinowski, D.S., Islam, M., and Bernhardt, P.V. (2006) Dipyridyl thiosemicarbazone chelators with potent and selective antitumor activity form iron complexes with redox activity. J. Med. Chem. 49, 6510-6521.

12. Sarel, S., Fizames, C., Lavelle, F., and Avramovici-Grisaru, S. (1999) Domain-structured N1,N2-derivatized hydrazines as inhibitors of ribonucleoside diphosphate reductase: redox-cycling considerations. J. Med. Chem. 42(2), 242-248.

13. Candéa, A.L.P., Ferreira, M.L., Pais, K.C., Cardoso, L.N.F., Kaiser, C.R., Henriques, M.G.M.O., Lourenço, M.C.S., Bezerra, F.A.F.M., and De Souza, M.V.N. (2009) Synthesis and antitubercular activity of 7-chloro-4quinolinylhydrazones derivatives. Bioorg. Med. Chem. Lett. 19, 6272-6274.

14. Chohan, Z.H., Arif, M., Shafiq, Z., Yaqub, M., and Supuran, C.T. (2006) In vitro antibacterial, antifungal and cytotoxic activity of some isonicotinoylhydrazide Schiff's bases and their cobalt (II), copper (II), nickel (II) and zinc (II) complexes. J. Enzyme Inhib. Med. Chem. 21(1), 95-103 
15. Sharma, V.K., Srivastava, S., and Srivastava, A. (2006) Synthesis and spectroscopic studies of novel mononuclear and binuclear ruthenium (III) complexes with bidentate and tridentate acyclic hydrazones. J. Coord. Chem. 59(12), 1321-1334.

16. De Souza, M.V.N., Wardell, J.L., Low, J.N., and Glidewell, C. (2006) Pyrrole-2-carbaldehyde isonicotinoylhydrazone monohydrate redetermined at 120K. Acta Crystallogr. C C62, 47-49.

17. Minoo, D., Peyman, S., and Mostafa, B. (2006) A facile procedure for the one-pot synthesis of unsymmetrical 2,5disubstituted 1,3,4-oxadiazoles. Tetrahedron Lett. 47, 6983-6986.

18. Fattorusso, C., Campiani, G., Kukreja, G., Persico, M., Butini, S., Romano, M.P., Altarelli, M., Ros, S., Brindisi, M., Savini, L., Novellino, E., Nacci, V., Fattorusso, E., Parapini, S., Basilico, N., Taramelli, D., Yardley, V., Croft, S., Borriello, M., and Gemma, S. (2008) Design, synthesis, and structure-activity relationship studies of 4-quinolinyland 9-acrydinylhydrazones as potent antimalarial agents. J. Med. Chem. 51(5), 1333-1343.

19. Canetti, J., Rist, E., and Grosset, R. (1963) [Measurement of sensitivity of the tuberculous bacillus to antibacillary drugs by the method of proportions. Methodology, resistance criteria, results and interpretation.] Rev. Tuberc. Pneumol. (Paris) 27, 217-272. [French]

20. Franzblau, S.G., Witzig, R.S., McLaughlin, J.C., Torres, P., Madico, G., Hernandez, A., Degnan, M.T., Cook, M.B., Quenzer, V.K., Ferguson, R.M., and Gilman, R.H.J. (1998) Rapid, low-technology MIC determination with clinical Mycobacterium tuberculosis isolates by using the microplate Alamar Blue assay. Clin. Microbiol. 36, 362-366.

21. Vanitha, J.D. and Paramasivan, C.N. (2004) Evaluation of microplate Alamar blue assay for drug susceptibility testing of Mycobacterium avium complex isolates. Diagn. Microbiol. Infect. Dis. 49, 179.

22. Reis, R.S., Neves, I., Jr., Lourenço, S.L.S.,; Fonseca, L.S., and Lourenço, M.C.S.J. (2004) Comparison of flow cytometric and Alamar Blue tests with the proportional method for testing susceptibility of Mycobacterium tuberculosis to rifampin and isoniazid. Clin. Microbiol. 42(5), 2247-2248.

23. Souza, M.C., Siani, A.C., Ramos, M.F.S., Jr., Limas, O.M., and Henrique, M.G.M.O. (2003) Evaluation of antiinflammatory activity of essential oils from two asteraceae species. Pharmazie 58(8), 582-586.

24. Carvalho, M.V., Monteiro, C.P., Siani, A.C., Valente, L.M.M., and Henriques, M.G.M.O. (2006) Investigations on the anti-inflammatory and anti-allergic activities of the leaves of Uncaria guianensis (Aublet) J. F. Gmelin. Inflammopharmacology 14(1-2), 48-56.

\section{This article should be cited as follows:}

Ferreira, M.L., Gonçalves, R.S.B., Cardoso, L.N.F., Kaiser, C.R., Candéa, A.L.P., Henriques, M.G.M.O., Lourenço, M.C.S., Bezerra, F.A.F.M., and De Souza, M.V.N. (2010) Synthesis and antitubercular activity of heteroaromatic isonicotinoyl and 7chloro-4-quinolinyl hydrazone derivatives. TheScientificWorldJOURNAL 10, 1347-1355. DOI 10.1100/tsw.2010.124. 

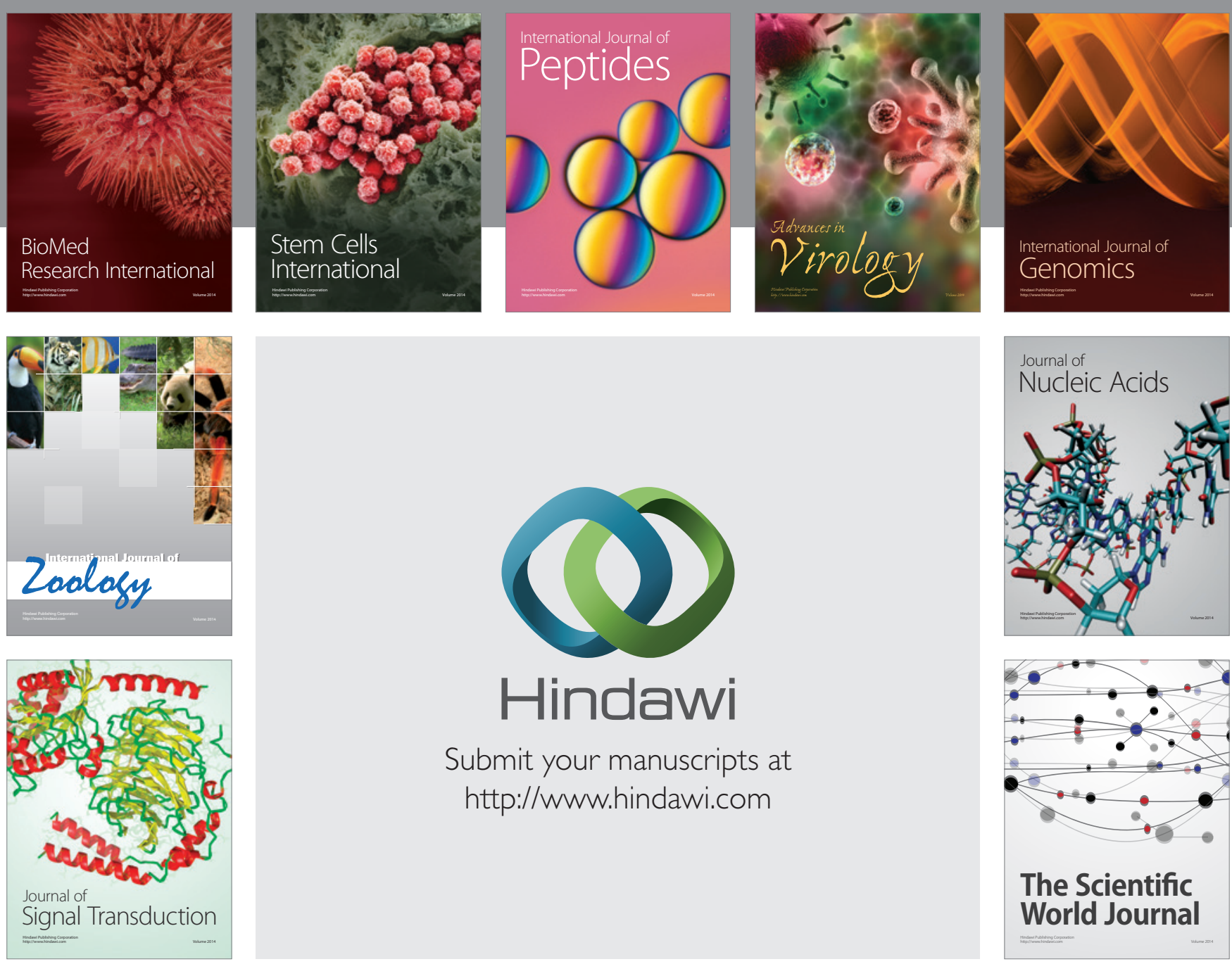

Submit your manuscripts at

http://www.hindawi.com
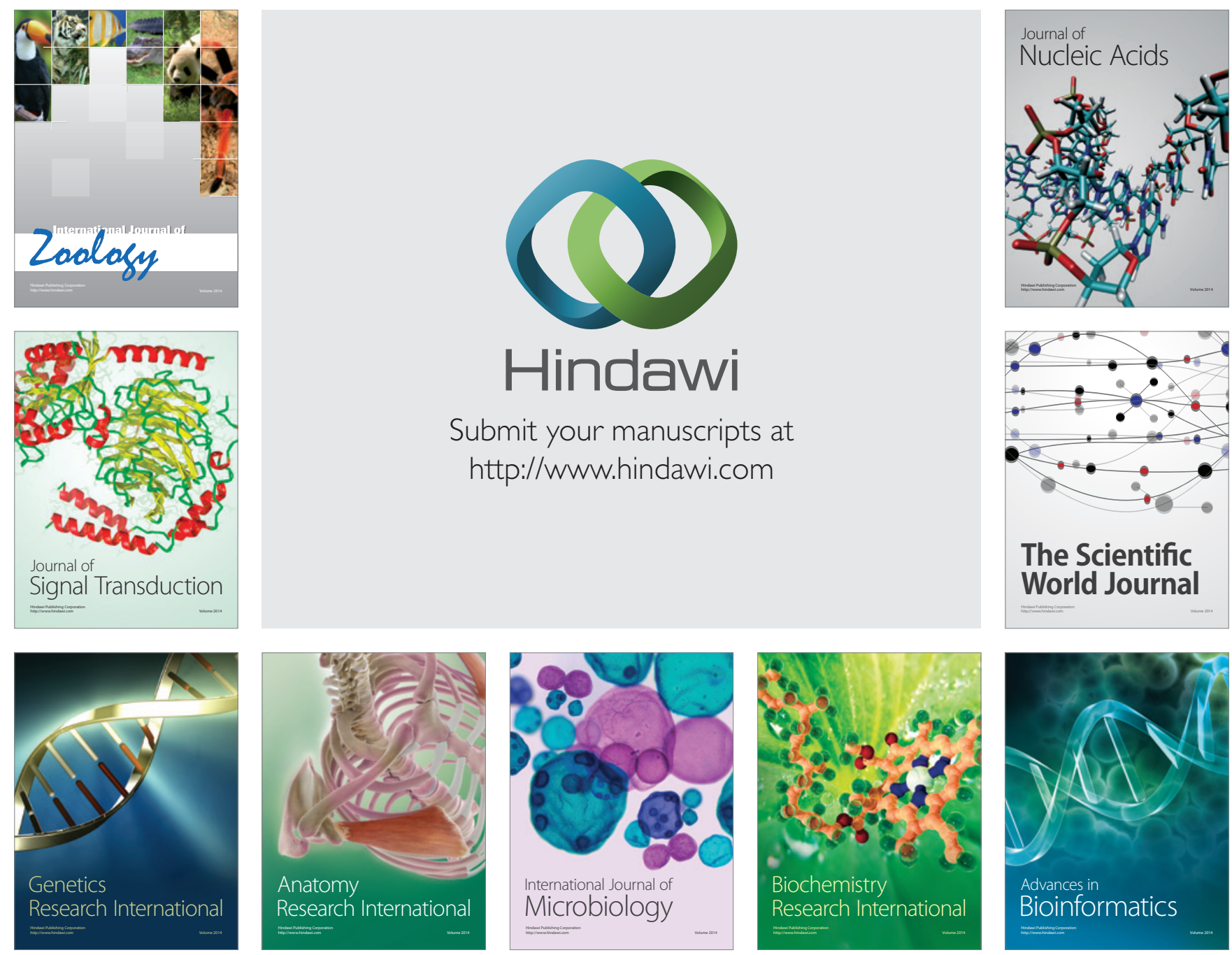

The Scientific World Journal
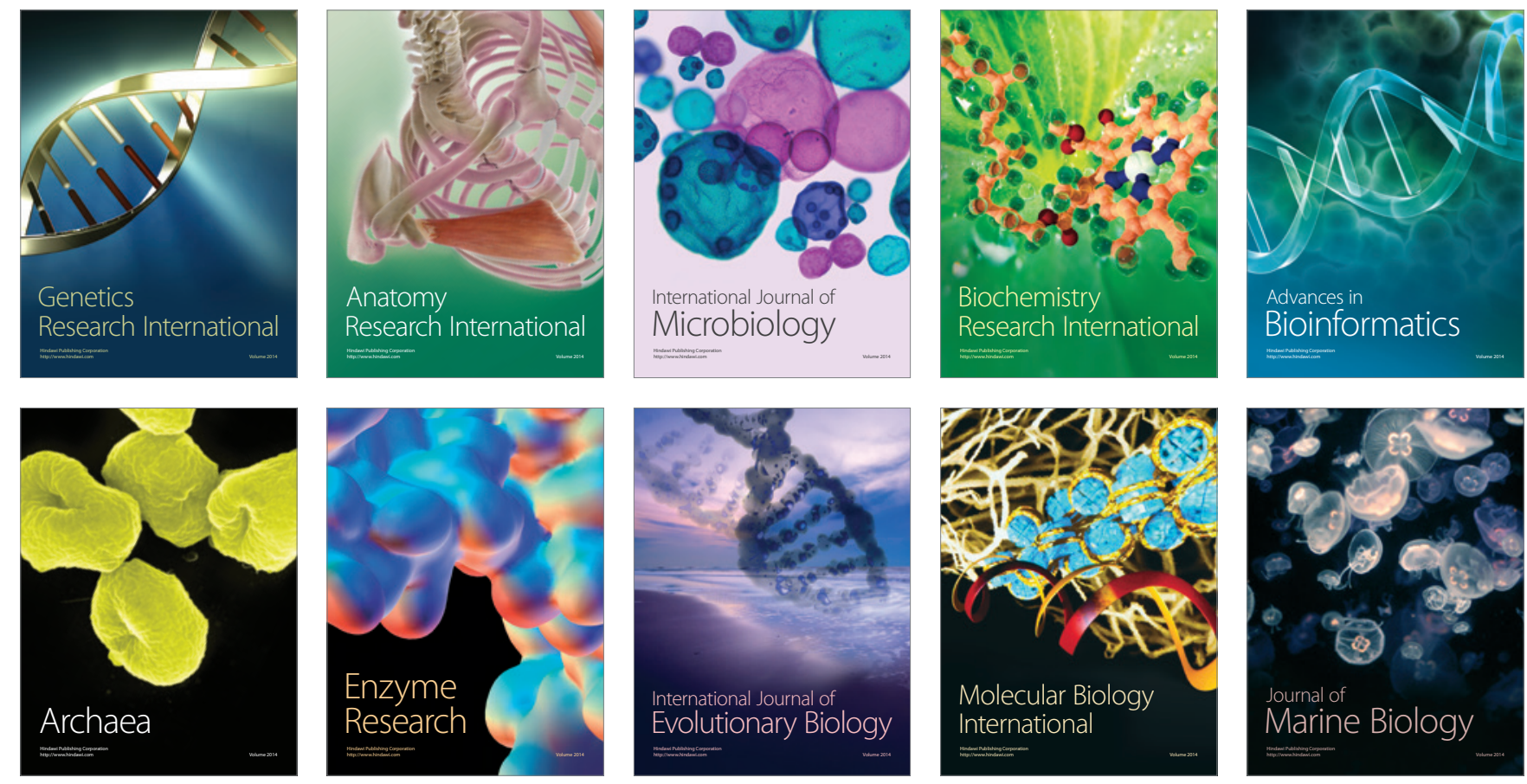